\title{
New records of Lepidoptera from Ukraine and description of a new species of Caloptilia Hübner, 1825 (Lepidoptera, Gracillariidae) from the mountains of Crimea
}

\author{
OLEKSIY V. BIDZILYA ${ }^{1}$, YuRI I. BUdASHKIN ${ }^{2}$
}

1 Institute for Evolutionary Ecology of the National Academy of Sciences of Ukraine, str. Academician Lebedev 37, 03143 , Kiev,Ukraine; olexbid@gmail.com

2 T.I. Vyazemsky Karadag Scientific Station - Nature Reserve RAS, Kurortnoye, Feodosia, Crimea, 298188; budashkin@ukr.net

http://zoobank.org/DD58C622-BD4B-47BE-A09E-51196633B205

Received 5 April 2017; accepted 31 May 2017; published: 4 August 2017

Subject Editor: Vazrick Nazari.

\begin{abstract}
Twenty-eight rare and poorly known lepidopteran species from eleven families are recorded from different regions of Ukraine. Eight species are recorded for the first time: Bucculatrix pannonica Deschka, 1982 (Bucculatricidae); Biselachista serricornis (Stainton, 1854) (Elachistidae); Aplota nigricans (Zeller, 1852) (Oecophoridae); Caulastrocecis pudicella (Mann, 1861), Scrobipalpa soffneri Povolný, 1964, Syncopacma polychromella (Rebel, 1902) (Gelechiidae); Phycita torrenti Agenjo, 1962 (Pyralidae) and Hodebertia testalis (Fabricius, 1794) (Crambidae). The hitherto unknown female of Filatima djakovica Anikin \& Piskunov, 1996, femina nova (Gelechiidae) is described based on material from the Kiev region. Caloptilia jailensis sp. n. (Gracillariidae) is described from the mountains of Crimea.
\end{abstract}

\section{Introduction}

The present contribution is a step towards preparing an inventory of the micromoth fauna for the Catalogue of Ukrainian Lepidoptera. According to our rough estimate at least 4000 species of Lepidoptera are known from Ukraine to date. As a result of our study of material collected by the authors and other collectors mainly in last years and identification of some specimens which remained unidentified for many years, 28 rare and poorly known Lepidoptera species from the families Tineidae, Bucculatricidae, Gracillariidae, Depressariidae, Elachistidae, Oecophoridae, Gelechiidae, Urodidae, Pterophoridae, Pyralidae and Crambidae were recorded from different regions of Ukraine. The annotated list of these species is given below. The adults and the male genitalia of Elachista pollinariella Zeller, 1839 and Bucculatrix pannonica Deschka, 1982 are illustrated. The differences between Ostrinia kasmirica (Moore, 1888) and O. nubilalis (Hübner, 1796) are briefly discussed, and the adults and the genitalia are illustrated for both species. We provide a description of the hitherto unknown female of Filatima djakovica Anikin \& Piskunov, 1996 (Gelechiidae) - a poorly known species which was rather unexpectedly recorded from the Kiev region. One species - Caloptilia jailensis sp. n. (Gracillariidae) is described based on material collected by the second author in the mountains of Crimea (Karabi-jaila, Aj-Petri-jaila and Babugan-jaila). 


\section{Material and methods}

The present study is based on material from the collection of the Zoological Museum, Kiev Taras Shevchenko National University, Ukraine (ZMKU) and T.I. Vyazemsky Karadag Scientific Station - Nature Reserve RAS, Crimea (KSS). The type material of Caloptilia jailensis sp. n., including the holotype, is deposited in the collection of ZMKU, and the rest of the paratypes in the KSS collection and in the collection of the Zoological Institute of the Russian Academy of Sciences, Saint-Petersburg, Russia (ZIN).

The adults were collected by light trap or by netting. Male and female genitalia were dissected and prepared using standard methods (Huemer and Karsholt 1999). Pinned specimens were photographed mainly with an Olympus E-410 digital camera attached to an Olympus SZX12 microscope. Slide-mounted genitalia were photographed with a Canon EOS 600D digital camera mounted on an Olympus U-CTR30-2 trinocular head combined with a Carl Zeiss microscope body. Sets of 10-20 images were taken for each specimen and assembled to deep-focused images using Helicon Focus 6 and edited in Adobe Photoshop CS5.

\section{Results}

\section{Tineidae}

\section{Monopis crocicapitella (Clemens, 1859)}

Material. 1 đ̂, Ukraine, Odessa reg., Kiliya distr., Vilkovo, 11.v.2014, leg. E. Khalaim. Genitalia slide: O. Bidzilya prep. no. 279/16.

Distribution. North Africa, Central and Southern Europe, Russia (Center of the European part, Western Caucasus, Lower Volga region), South Africa, South Asia, North and South America, Australia, New Zealand (Zagulajev 1960; Petersen and Gaedike 1996; Baryshnikova 2008). It is also known from Crimea (Budashkin 2004).

\section{Bucculatricidae}

\section{Bucculatrix pannonica Deschka, 1982}

Figs 1, 2

Material. 2 đૈ, Ukraine, Odessa reg., Ivanovskiy distr., Severinovka, at light, 30.iv.2016, leg. A. Zhakov. Genitalia slide: O. Bidzilya prep. no. 274/16.

Distribution. Austria, Slovakia, Hungary (Deschka 1982; Baraniak 1996). New for Ukraine.

\section{Gracillariidae}

Parornix tenella (Rebel, 1919)

Material. 1 กิ, Ukraine, Nikolaev reg., Aktovo vic., Arbuzinka river canyon, at light, 3.vi.2016, leg. O. Bidzilya. 


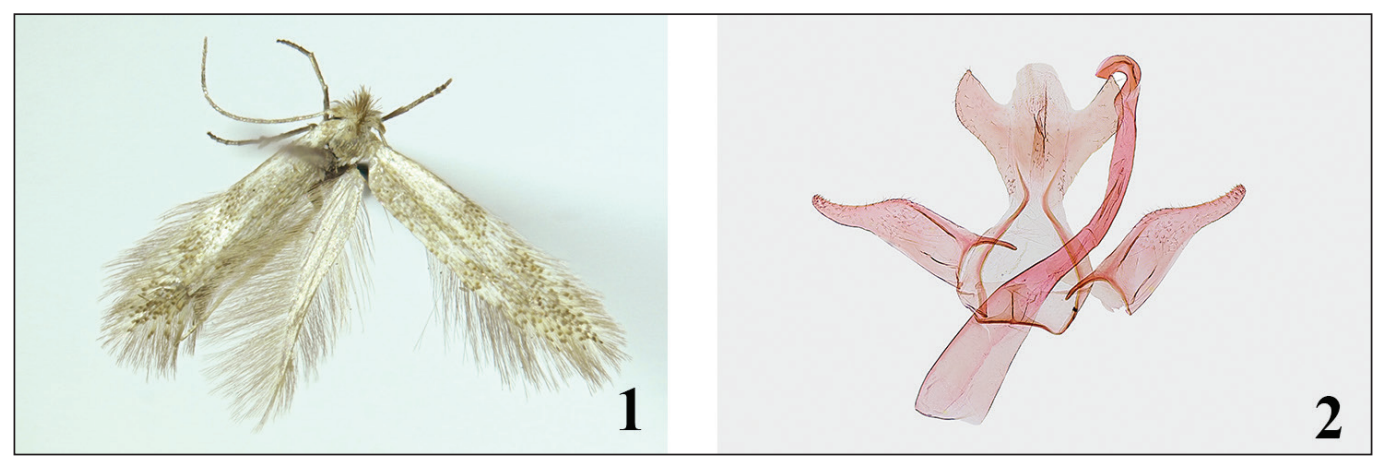

Figures 1, 2. Bucculatrix pannonica. 1. Adult; 2. Male genitalia.

Distribution. Spain, Portugal, Italy (with Sicily), Austria, Croatia, Czech Republic, Slovakia, Hungary, Romania (Buszko 1996; De Prins and De Prins 2016). It is also known from Crimea (Budashkin 2004; Bidzilya et al. 2006).

\section{Caloptilia jailensis sp. $\mathrm{n}$.}

http://zoobank.org/0AEBBE4E-C57F-4E01-99EC-A19758D1A839

Material. Holotype $\widehat{\jmath}$, "Crimea, Karabi-jaila, 1100 m, 8.vi.1994, in the morning on sunrise, leg. Yu. Budashkin” (ZMKU). Genitalia slide: O. Bidzilya prep. no. 627/14 (ZMKU). Paratypes: 6 $\uparrow, 1$, , same data as holotype, Genitalia slide: O. Bidzilya prep. no. 628/14우 (ZMKU, KSS, ZIN); 1 ㅇ, Crimea, Aj-Petri, 1200 m, at light, 14.vi.2002, leg. Yu. Budashkin (KSS); 1 , Crimea, Crimean Reserve, Babugan-jaila, Bolshaja Chuchel mt., 1350 m, 3.vi.2006, evening collection, leg. Yu. Budashkin (KSS).

Description. Adult (Fig. 3). Sexual dimorphism not observed. Wing span 9.0-11.0 mm. Head light yellow, densely covered with erected scales, frons greyish-brown, smooth scaled. Scape and flagellum greyish-brown, without light rings. Labial palpus long, sickle-shaped, greyish-brown, inner surface of segment 2 and apical portion of segment 3 lighter, yellowish-brown. Maxillary palpus long and narrow, greyish-brown. Thorax and tegulae light yellow. Forewing comparatively broad (ratio length/width $=0.16$ ), lanceolate. Ground colour of forewing greyish-brown. Wing pattern is very distinct: broad (about $1 / 3$ width of forewing) light yellow patch from base to half length of forewing along the dorsal margin, sub-ovate yellowish-orange tornal spot at $2 / 3$ forewing length, large rounded to ovate light orange spot in middle width from $3 / 4$ length to wing apex. Cilia light brown from tornus to outer margin of forewing, then, along outer margin of forewing slightly lighter than ground colour, with well-developed medial dividing dark line. Hindwing light grey, more or less unicoloured, cilia slightly lighter, greyish-brown. Abdomen greyish-brown, last segment covered with yellowish-orange hair-like scales in male; male abdominal segments VII-VIII with coremata represented by paired tufts (two on one side and two on the opposite side) of hairlike scales of equal length. Male tergum VIII subrectangular with long and narrow anteromedial arm (Fig. 4c). 


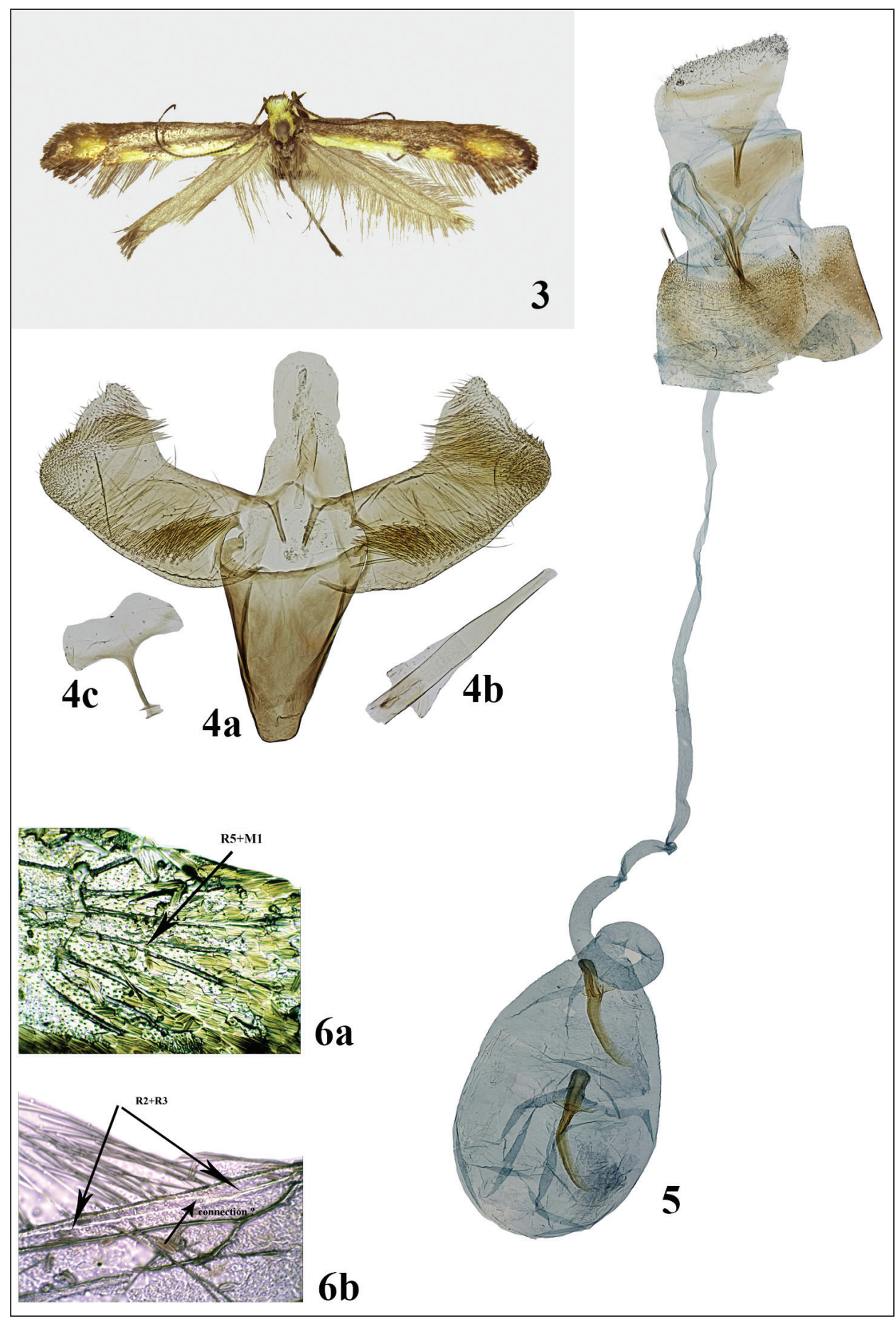

Figures 3-6. Caloptilia jailensis sp. n. 3. Adult, holotype; 4. Male genitalia and tergum VIII, holotype, genitalia slide: O. Bidzilya prep. no. 627/14; a. male genitalia; b. phallus removed; c. tergum VIII; 5. Female genitalia, genitalia slide: O. Bidzilya prep. no. 628/14; $\mathbf{6}$. Fragment of wing venation; a. forewing; $\mathbf{b}$. hindwing. 
Male genitalia (Fig. 4a, b). Tuba analis membranous, about as broad as distal portion of tegumen, far protruded over the top of tegumen. Subscaphium narrow. Tegumen longer than broad basally, weakly narrowed distally, with deep triangular anteromedial emargination. Valvae about twice as long as broad, slightly asymmetrical, dorsal margin with large subtriangular projection in distal $1 / 3$, covered with dense long setae along dorsal and outer margin, dorsal branch of basal process 1.5 times longer than ventral branch. Saccus stout, of moderate length, very broad at base, then gradually narrowed apically, apex truncate. Phallus about as long as valva, narrowly bottle-shaped, without cornuti.

Female genitalia (Fig. 5). Papillae anales membranous, rather large, densely covered with short setae. Both pairs of apophyses thick and short, apophyses anteriores slightly longer than apophyses posteriores. Segment VIII subrectangular, postvaginal plate membranous but strongly edged. Antrum not developed. Ductus bursae long and narrow, the proximal portion weakly broadened and coiled before corpus bursae. Ostium a small indistinct hump between segments VII and VIII. Bursa copulatrix large, egg-shaped, signum paired, long and narrow, claw-shaped, weakly curved.

Differential diagnosis. The new species externally remotely resembles Caloptilia aurantiaca (Wollaston, 1858) from the Canary, Madeira and Azores Islands, having a forewing with dark costal and lighter dorsal parts. It differs from the latter and other Caloptilia species by having distinct yellowish-orange spots in the distal half of the forewing. The male genitalia are most similar to those of Caloptilia cuculipennella (Hübner, 1796), but the valva is about twice as long as broad, whereas in C. cuculipennella it is three times as long as broad; the saccus is truncate rather than tapered in C. cuculipennella, and the coremata are of different shape. The female genitalia most resemble those of Caloptilia stigmatella (Fabricius, 1781) but can easily be recognized by the membranous, more weakly developed postvaginal plate, a different location of the ostium and the shorter pairs of apophyses.

Distribution. Known only from the mountains of Crimea.

Life history. Host plant unknown. The new species was collected in horizontal meadow-steppes at the altitude of $1100 \mathrm{~m}$ on Karabi-jaila (Figs 7, 8) and at $1200 \mathrm{~m}$ on Aj-Petri-jaila. The single female from Babugan-jaila was collected on a rather steep slope of Bolshaja Chuchel Mountain at an elevation of about $1350 \mathrm{~m}$. All specimens were collected by sweeping over the grass with a net except for one female which was collected at light on Aj-petri jaila.

Etymology. The specific name refers to the habitats of the new species - jaila (from Crimean-Tatar "yayla", high mountains summer pastures), the open horizontal slightly hilly mesophytic plateaus at elevations of 1000-1500 m covered mainly with grass, which are very characteristic for the highest parts of Crimean mountains.

Remarks. The generic assignment of the new species is rather unclear. The presence of R2+R3 in hindwing is characteristic for the Gracillaria-group (Huemer et al. 2016); however, the stalked M5+R1 in forewing (Fig. 6a), the connection between R2+R3 and R1 in hindwing (Fig. 6b) and rather broad forewing were not observed in any genera of this group. We provisionally place the new species in the genus Caloptilia, subfamily Gracillariinae (Kawahara et al. 2017) based on the male genitalia characters until its position within Gracillariidae can be clarified by DNA studies and further examination of the wing venation. 


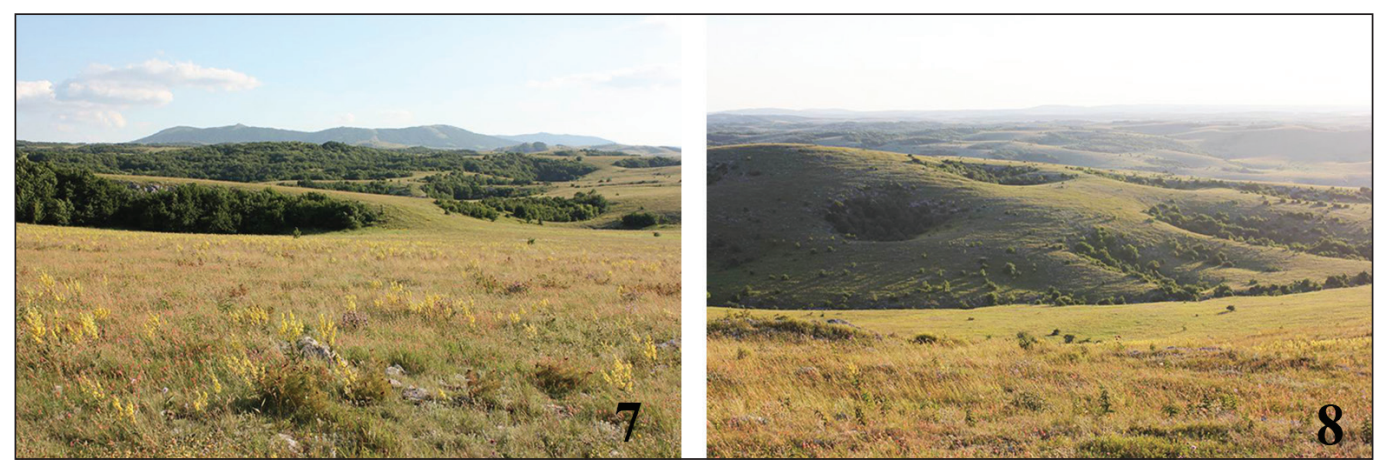

Figures 7, 8. Karabi-jaila, Crimea. Type locality of Caloptilia jailensis sp. n. (photographs S. P. Ivanov).

\section{Depressariidae}

\section{Agonopterix yeatiana (Fabricius, 1781)}

Material. 3 ô, Ukraine, Odessa reg., Kiliya distr., Vilkovo, 11.v, 14-15.viii.2014, leg. E. Khalaim. Genitalia slide: O. Bidzilya prep. no. 12/17.

Distribution. North Africa, Central and Southern Europe, Russia (Belgorod region, Krasnodar region), Transcaucasia (Georgia, Azerbaijan) (Lvovsky 2008). It is also known from Crimea (Lvovsky 2006).

\section{Elachistidae}

\section{Elachista pollinariella Zeller, 1839}

Figs 9,10

Material. 2 ô, Ukraine, Kiev reg., Borodjanka distr., 2 km NW Potashnja, at light, 27.v.2016, leg. O. Bidzilya. Genitalia slide: O. Bidzilya prep. no. 273/16.

Distribution. Northern and Central Europe, Russia (Kaliningrad region, North-West and Center of the European part, Western Caucasus, Middle Volga region, South Ural) (Parenti 1996; Kaila et al. 2003; Sinev 2008a). In Ukraine it was known from Lvov and Tchernovtsy regions (Hormuzaki 1907; Schille 1930; Bidzilya et al. 2016).

\section{Elachista gormella Nielsen \& Traugott-Olsen, 1987}

Material. 1 đै, Ukraine, Odessa reg., 4 km E Gradenitsy, 1.v.2014, leg. E. Khalaim.

Distribution. Spain (with Balearic Islands), Portugal, France, Austria, Italy (with Sardinia), Czech Republic, Slovakia, Hungary, Russia (? Middle Volga region) (Parenti 1996; Sinev 2008a). It is also known from Crimea (Bidzilya et al. 2016). 


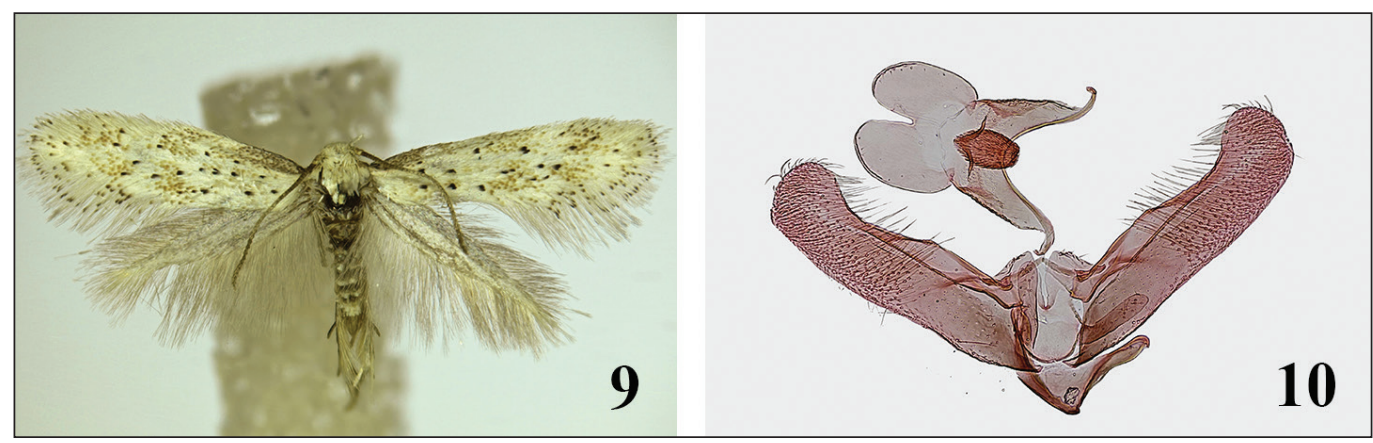

Figures 9, 10. Elachista pollinariella. 9. Adult; 10. Male genitalia.

\section{Elachista bisulcella (Duponchel, 1843)}

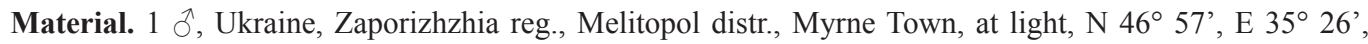
28.viii.2015, leg. A. Zhakov.

Distribution. Northern and Central Europe, Russia (Kaliningrad region, North-West of the European part, Middle Volga region, Altai) (Kaila 1992; Parenti 1996; Sinev 2008a). In Ukraine it was known from Lvov region only (Nowicki 1860; Schille 1930, as zonariella Tengström, 1848.; Bidzilya et al. 2016).

\section{Biselachista serricornis (Stainton, 1854)}

Material. 1 ô, Ukraine, Rivne reg., Klevan 9 km N, Chervona Kalyna, 23.vii.2014, leg. O. Bidzilya; 1 ô, 1 q, Ukraine, Odessa reg., Kiliya distr., Vilkovo, 8, 10.viii.2016, leg. E. Khalaim.

Distribution. Northern and partially Central Europe, Russia (Northwest and Center of the European part) (Parenti 1996; Sinev 2008). New for Ukraine.

\section{Oecophoridae}

\section{Batia lunaris (Haworth, 1828)}

Material. 3 ô, Ukraine, Odessa reg., Ivanovskiy distr., 5 km NW Severinovka vill., at light, 8.vi.2015, leg. O. Bidzilya. Genitalia slide: O. Bidzilya prep. no. 129/15.

Distribution. North Africa, Central and Southern Europe, Asia Minor, North America (Lvovsky 1996). In Ukraine it was known from Nikolajev region only (Bidzilya et al. 2013). The record from the Kiev region (Ljubomudrov 1917, Sovinskiy 1938) needs verification (Tokar et al. 2003). 


\section{Aplota nigricans (Zeller, 1852)}

Material. 4 đ, Ukraine, Nikolaev reg., Actovo vic., Arbuzinka river canyon, at light, 3.vi.2016, leg. O. Bidzilya.

Distribution. Central and Southern Europe (Lvovsky 2006). New for Ukraine.

\section{Gelechiidae}

Caulastrocecis pudicella (Mann, 1861)

Material. 1 Jै, Ukraine, Lugansk reg., S vic. of Severedonetsk, dacha near Kleshnja lake, at light, 24.vi.2015, leg. S. Demianenko. Genitalia slide: O. Bidzilya prep. no. 173/16.

Distribution. Spain, Slovakia, Croatia, Romania, Asia Minor (Elsner et al. 1999). New for Ukraine.

\section{Metzneria intestinella (Mann, 1864)}

Material. 1 ô, Ukraine, Odessa reg., Ivanovskiy distr., Severinovka vic., at light, 2.v.2016, leg. A. Zhakov; 1 §, Zaporozhie reg., Akimovka distr., Atmanai, 17.iv.2016, leg. A. Zhakov.

Distribution. Portugal, Spain, France, Italy, Croatia, Macedonia, Slovakia, Hungary, Albania, Greece, Romania, Bulgaria (Karsholt and Riedl 1996; Elsner et al. 1999). It is also known from Crimea (Bidzilya et al. 2014).

\section{Ornativalva plutelliformis (Staudinger, 1859)}

Material. 1 , Ukraine, Kherson reg., Arabatskaya strelka, Schastlivtsevo, at light, 20.viii.2015, leg. O. Bidzilya.

Distribution. Spain (with Canary Islands), Portugal (with Madeira), North Africa, France (with Corsica), Italy (with Sardinia and Sicily), Malta, Macedonia, Hungary, Romania, Greece, Crete, Cyprus, Russia (Lower Volga region, Kalmykia), Iran, Central Asia (Uzbekistan), Pakistan, NW China (Karsholt and Riedl 1996; Elsner et al. 1999; Ponomarenko 2008; Falkovitsh and Bidzilya 2009). In Ukraine it was known from Zaporozhie region. It is also found in Crimea (Bidzilya and Budashkin 2004; Budashkin 2004).

\section{Chionodes electella (Zeller, 1839)}

Material. 2 đ̃, Ukraine, Kiev, Kiev National Taras Shevchenko University, Laboratory of Zoological Museum, on windowsill, 26.vi.2015, 24.vi.2016, leg. O. Bidzilya. 
Distribution. Northern and Central Europe, Russia (North of European part, Amur region) (Huemer and Karsholt 1999; Ponomarenko 2008). In Ukraine it was known from Chernigov, Lvov and Ivano-Frankovsk regions (Schille 1930; Gershenzon 1988; Bidzilya et al. 2006).

Remarks. Two males were found in late June on a windowsill in the laboratory of the Zoological Museum during for two successive years. We assume that a population of the species exists on its host plant, a fir tree (Picea abies (L.) Karst. (Pinaceae) growing in the yard about $20 \mathrm{~m}$ away from the window. Ch. electella inhabits coniferous forests within the range of fir trees in western Ukraine. However, the species has also been recorded in artificial plantations (mainly in parks) of Picea abies in the forest zone in northern Ukraine (Gershenzon 1988). Our record confirms that Ch. electella is broadly distributed outside of the range of its host plant and may exist on single trees growing in isolation in urban habitats. This is similarly true for another gelechiid species, Dichomeris latipennella (Rebel, 1937), which has also been recorded from Kiev based on a single specimen bred from fir cones gathered under a single tree (Bidzilya et al. 2011).

\section{Filatima djakovica Anikin \& Piskunov, 1996, femina nova}

Material. 4 ภ, 1 †, Ukraine, Kiev reg., Mironovka distr., 4 km W Khodorov vill., at light, 24.v.2015, leg. O. Bidzilya. Genitalia slide: O. Bidzilya prep. no. 10/17 ऊ̂; 11/17우.

Description. Herewith we provide the description of the hitherto unknown female.

Female (Fig. 11a). Wingspan $12.1 \mathrm{~mm}$. Head dirty white, neck mottled with brown, segment 2 of labial palpus dirty-white, outer and lower surface light grey mixed with brown-tipped scales, base brown, segment 3 whitish-brown, scape brown with some rare whitish scales, flagellum brown white-ringed in basal half. Thorax, tegulae and forewing covered with grey brown-tipped scales, fold light brown with indistinct black dash on base, three very indistinct black spots surrounded with light brown in cell, cilia light grey black-tipped. Hindwing light grey in basal half and dark grey in distal half, cilia grey.

Female genitalia (Fig. 12). Segment VIII trapezoidal, slightly narrowed distally; antrum narrow, tubular, of even width, the posterior margins strongly sclerotized, lateral sclerites large, rounded, densely covered with small spines; ductus bursae short and broad, covered with moderately long spines, with two elongated patches of lateral sclerotization; corpus bursae prolonged, signum a rounded plate with two basal short thorn-shaped processes.

Remarks. The sternum VIII of $F$. djakovica is most similar to that of $F$. textorella (Chrétien, 1908), but the lateral sclerites are larger. The antrum resembles that of F. incomptella (Herrich-Schäffer, 1854) but lateral sclerotization is poorly developed and the spines are larger. The signum is similar to that of F. tephriditella (Duponchel, 1844) but it is more weakly edged and its lateral process is longer.

Distribution. Romania (Rákosy et al. 2003), Russia (Vladimir and Saratov regions) (Anikin and Piskunov 1996; Piskunov and Uskov 2006). In Ukraine it was known from Lugansk region only (Bidzilya and Budashkin 2004).

Notes. The single female differs from males in more uniformly greyish forewing with poorly expressed spots and in smaller size: the wingspan is $12.1 \mathrm{~mm}$ whereas the four males have a wing- 


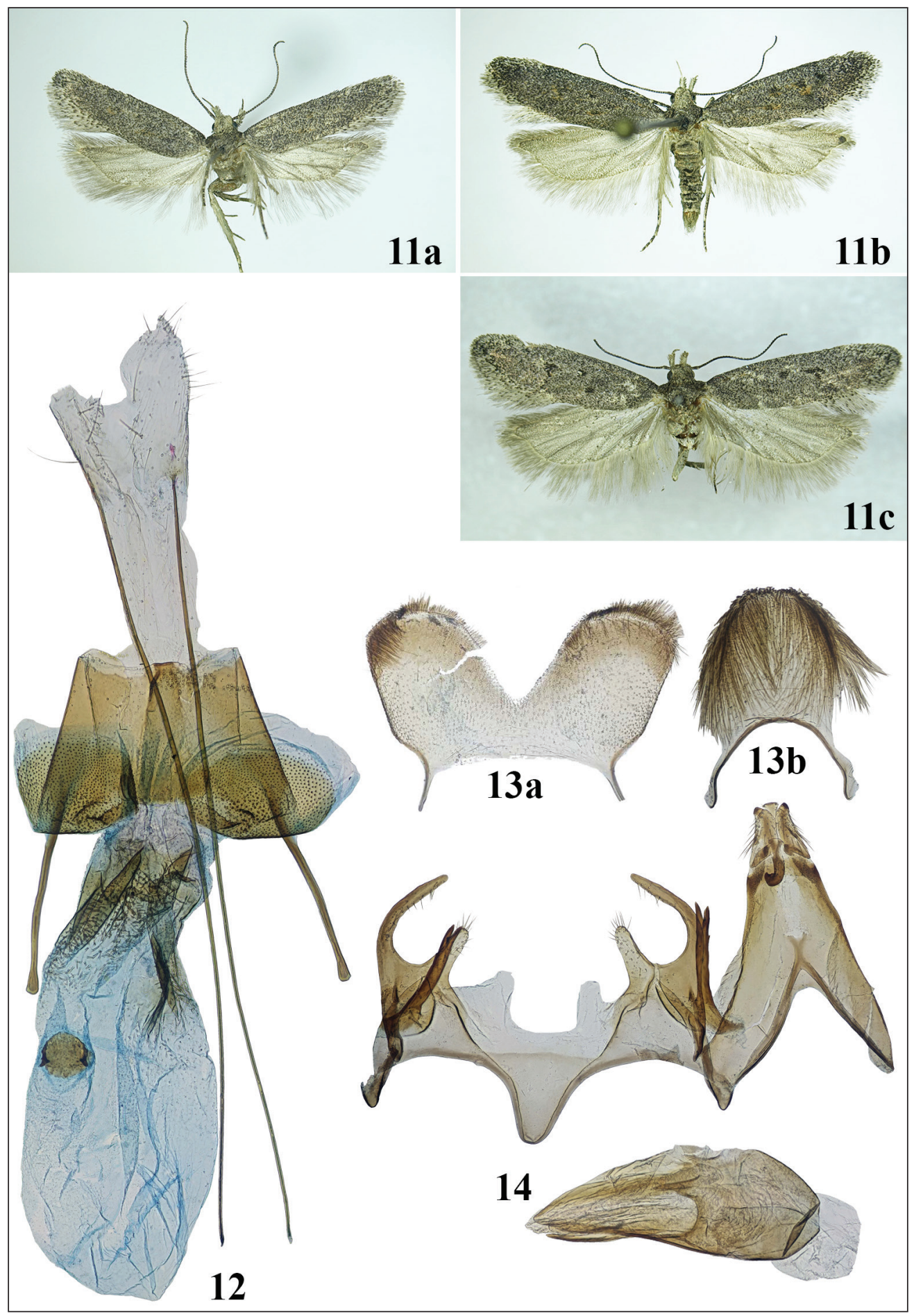

Figures 11-14. Filatima djakovica. 11. Adult; a. female; b, c. males; 12. Female genitalia; 13. Male abdominal segment VIII; a. sternum; b. tergum; 14. Male genitalia with phallus removed. 
span 14.0-17.0 mm. The males are rather variable (Fig. 11b, c): the ground colour of the forewing varies from grey to brown, black spots in cell are usually hardly visible but can be well developed in some specimens. The male genitalia of our specimens (Figs 13,14) match the holotype except for more weakly developed cornuti in the phallus. This variation has already been mentioned for specimens from the Vladimir region of Russia (Piskunov and Uskov 2006).

\section{Scrobipalpa soffneri Povolný, 1964}

Material. 4 đ, Ukraine, Kherson reg., 10 km NE Radensk, Oleshki sands, 6.vi.2015, leg. O. Bidzilya.

Distribution. Bulgaria, Russia (Volgograd region, South Ural), Turkmenistan (Huemer and Karsholt 2010). New for Ukraine.

\section{Scrobipalpa mixta Huemer \& Karsholt, 2010}

Material. 4 đ̂, Ukraine, Zaporozhie reg., Akimovka distr., Atmanai, 17.iv.2016, leg. A. Zhakov.

Distribution. Macedonia, (?) Albania. It is also known from Crimea (Huemer and Karsholt 2010).

\section{Klimeschiopsis kiningerella (Duponchel, 1843)}

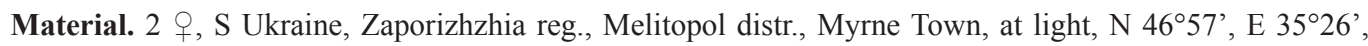
28.viii.2015, leg. A. Zhakov.

Distribution. Mountains of Central Europe, Scandinavia, Russia (Southern Ural) (Ponomarenko 2008; Huemer and Karsholt 2010; Junnilainen et al. 2010). In Ukraine it was known from Lvov region only (Schille 1930).

\section{Sophronia semicostella (Hübner, 1813)}

Material. 6 ô, Ukraine, Kiev reg., Borodjanka distr., 2 km NW Potashnja, at light, 27.v.2016, leg. O. Bidzilya.

Distribution. Europe, Russia (North-West and Centre of the European part, Volga region) Turkey, Kazakhstan (?) (Elsner et al. 1999; Ponomarenko 2008; Kemal and Koçak 2017). In Ukraine it was known from Lvov region only (Schille 1930).

\section{Syncopacma polychromella (Rebel, 1902)}

Material. 1 đ̊, Ukraine, Odessa reg., Beljaevskiy distr., 4 km E Gradentsu, 12.vi.2016, leg. S. Novitckiy. 
Distribution. Spain (with Canary Islands), Portugal (with Madeira), Gibraltar, Italy (with Sicily), Austria, Malta, Croatia, Macedonia, Czech Republic, Greece, Crete, Cyprus, Middle East, Middle Asia, Mongolia, India. Introduced to Denmark, England and South Africa (Karsholt and Riedl 1996; Falkovitsh and Bidzilya 2009). New for Ukraine.

\section{Urodidae}

Wockia asperipunctella (Bruand, 1850)

Material. 1 , , Ukraine, Kiev reg., Brovary distr., Knjazhichi, at light, 29.vii.2016, leg. A. Zykov.

Distribution. France, Germany, Italy, Austria, Norway, Sweden, Czech Republic, Croatia, Slovenia, Poland, Slovakia, Hungary, Finland, Estonia, Latvia, Romania, Russia (European part and Altai), North America (Sinev 2016). In Ukraine it was known from Lvov region only (Schille 1930).

\section{Pterophoridae}

Agdistis satanas Milliere, 1876

Material. 1 đ̊, Ukraine, Odessa reg., Kiliya distr., Vilkovo vic., Zhebrijanskaya grjada, 5-7.viii.2016, leg. E. Khalaim.

Distribution. North Africa, Southern and partially Central Europe, Asia Minor, Middle East (Arenberger 1995). It also known from Crimea (Budashkin and Savchuk 2008).

\section{Stenoptilodes taprobanes (Felder \& Rogenhofer, 1875)}

Material. 1 đ, Ukraine, Odessa reg., Kiliya distr., Vilkovo, 3-7.viii.2014, leg. E. Khalaim.

Distribution. Spain (with Canary Islands), Portugal (with Madeira), North Africa, France, Malta, Italy (with Sicily), Finland, Greece, Crete, Cyprus, Bulgaria, Asia Minor, Iran, Russia (Southern Primorye), India, Japan (Zagulajev 1986; Bigot and Picard 1996; Ustjuzhanin and Kovtunovich 2008). It is also known from Crimea (Budashkin 2006).

\section{Pyralidae}

\section{Phycita torrenti Agenjo, 1962}

Material. 4 Ô, 13 o, [Ukraine] Crimea, Karadag, biostancija, at light, 29.viii.1985, 10.ix.1986, 26.vii17.x.1987, 28, 30.viii.2003, 20.viii.2014, leg Yu. Budashkin. Genitalia slide: O. Bidzilya prep. no. 640/14우, $641 / 14 \hat{\jmath}$, no. $75 / 15 \hat{\jmath}$.

Distribution. Portugal, Spain, France, Croatia, Hungary (Pastoralis and Slamka 2015). New for Ukraine. 


\section{Pempelia albariella (Zeller, 1839)}

Material. 1 ô, Ukraine, Odessa reg., Ivanovskiy distr., Russkaya Slobodka vic., at light, 4.vi.2016, leg. O. Bidzilya.

Distribution. Spain, France, Italy (with Sicily), Croatia, Macedonia, Slovakia, Hungary, Romania, Russia (Middle and Lower Volga regions), Transcaucasia, Middle Asia (Sinev 1986, 2008b; Speidel 1996). It is also known from Crimea (Budashkin 2004).

\section{Crambidae}

\section{Ostrinia kasmirica (Moore, 1888)}

Material. 1 ô, Ukraine, Lugansk reg, S vicinity of Severodonetsk, dacha near Kleshnya lake, at light, 31.vii.2015, leg. S. Demyanenko. Genitalia slide: O. Bidzilya prep. no. 444/16; 1 , Kherson reg., Arabatskaya strelka, Schastlivtsevo, 2.viii.2016, leg. O. Bidzilya, Genitalia slide: O. Bidzilya prep. no. 37/17; 1 , [Kazakhstan], Ural m., Uralsk, 6.vii.1913. Genitalia slide: O. Bidzilya prep no. 449/16.

Remarks. O. kasmirica resembles externally O. nubilalis (Hübner, 1796) and O. scapulalis (Walker, 1859) but differs from both related species in narrower and more serrated light fascia on the hindwing (Figs 15, 16). Additionally, O. kasmirica can be distinguished from O. scapulalis by the hindtibia which is not thick and hairy in the male (Slamka 2013). The male genitalia of $O$. kasmirica differ from those of $O$. scapulalis and $O$. nubilalis in the bilobed rather than trilobed uncus and the sacculus bears more spines (Figs 17, 19). The female genitalia of O. kasmirica are characterized by a narrow and not wrinkled sternum VIII in contrast to distinctly wrinkled and rather broad sternum VIII in related species (Figs 18, 20). In summary, O. kasmirica can easily be distinguished by the genitalia of both sexes, whereas the separation of two related European species, O. nubilalis and O. scapulalis, remains rather problematic (Slamka 2013: 59).

Distribution. Ukraine, Russia (South Ural, Southern Siberia), Western Kazakhstan (Uralsk), Turkmenistan (ssp. eurasiatica Mutuura \& Munroe, 1970), Pakistan, India (ssp. kasmirica) (Slamka 2013). In Ukraine it was known from Dnepropetrovsk region (Kosakevich 1978). It is also found in Crimea (Budashkin 2004).

\section{Hodebertia testalis (Fabricius, 1794)}

Material. 1 ô, 1 q, Crimea, Karadag, biostancija, at light, 20.ix, 6.x.2016, leg. Yu. Budashkin.

Distribution. Native to subtropics and tropics, probably resident in the Mediterranean area: Spain (with Canary Islands), Portugal (with Madeira), North Africa, Malta, France, Italy (with Sicily), Croatia, Greece, Asia Minor, Middle East. The records from Crimea as well as the single records from the British Isles and Switzerland belong most likely to migrants (Slamka 2013). New for Ukraine. 


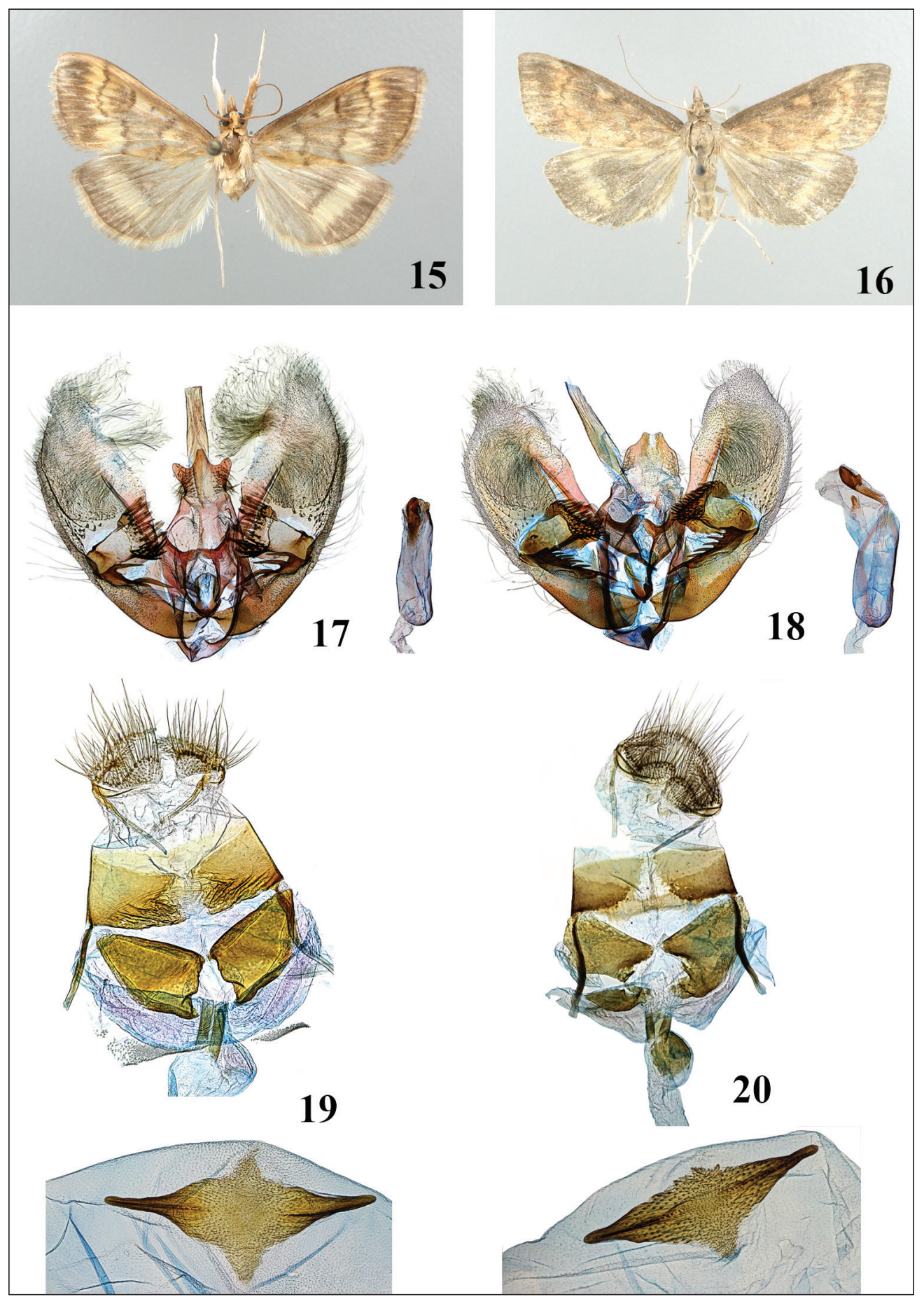

Figures 15-20. Ostrinia spp. 15, 17, 19. O. nubilalis: 15. Adult, male, Lugansk reg.; 17. Male genitalia, Kiev reg.; 19. Female genitalia, Kiev reg. 16, 18, 20. O. kasmirica: 16. Adult, female, Kherson reg.; 18. Male genitalia, Lugansk reg.; 20. Female genitalia, Kherson reg. 


\section{Acknowledgements}

We cordially thank Jaroslaw Buszko (Torun, Poland), Paolo Triberti (Verona, Italy) and Carlos Lopez-Vaamonde (Orléans, France) for their comments on the systematic position of $C$. jailensis as well as to Camiel Doorenweerd (Leiden, Netherlands) and two anonymous reviewers for the improvement of the manuscript and linguistic corrections. We express our gratitude to our Ukrainian colleagues and collectors Sergei Demyanenko (Severodonetsk), Eugeniy Khalaim (Odessa), Sergei Novitckiy (Odessa), Aleksandr Zhakov (Zaporozhie) and Aleksandr Zykov (Kiev) for providing their own material to us. We are thankful to Sergei Ivanov (Simpheropol) for allowing us to publish his photographs of Karabi-jaila.

\section{References}

Anikin VV, Piskunov VI (1996) New species of gelechiid moths from Saratov Province, Russia (Lepidoptera, Gelechiidae). Zoosystematica Rossica 4: 171-175.

Arenberger E (1995) Pterophoridae. In Amsel HG, Gregor F and Reisser H (Eds) Microlepidoptera Palaearctica 9. G. Braun, Karlsruhe, 258 pp. [153 tafs.]

Baraniak E (1996) Bucculatricidae. In: Karsholt O, Razowski J (Eds) The Lepidoptera of Europe. A distributional checklist. Apollo Books, Stenstrup, 47-48.

Baryshnikova SV (2008) Tineidae. In: Sinev SYu (Ed) Catalogue of the Lepidoptera of Russia. KMK Scientific Press Ltd., St. Petersburg, Moscow, 27-32. [In Russian]

Bidzilya A, Budashkin Yu, Noreika R (2006) Description of Parornix altaica sp. n. with new distributional data on Parornix mixta (Triberti), P. tenella (Rebel) and P. kugitangi Noreika (Lepidoptera, Gracillariidae). Acta Zoologica Lituanica 16(3): 210-214. https://doi.org/10.1080/13921657.2006.10512733

Bidzilya AV, Budashkin YuI, Goloborod'ko KK, Demyanenko SA, Zhakov AV (2013) New and interesting records of Microlepidoptera (Lepidoptera) from Ukraine. Contribution 2. Eversmannia 33: 23-30. [+ pl. 2, In Russian]

Bidzilya O, Budashkin Yu, Kljuchko Z, Kostjuk I, Kullberg J (2006) A contribution to the knowledge of Lepidoptera of the south-eastern part of the Ukrainian Carpathian. Proceedings of Zoological museum Kiev Taras Shevchenko national university 4: 21-52. [In Ukrainian]

Bidzilya O, Budashkin Yu, Zhakov A (2016) Checklist of grass-mining moths of Ukraine with description of one new species (Lepidoptera: Elachistidae). SHILAP Revista de lepidopterologia 44(173): 17-38.

Bidzilya OV, Budashkin YuI (2004) New records of Lepidoptera from Ukraine. Proceedings of Zoological museum Kiev Taras Shevchenko national university 2: 59-68. [In Ukrainian]

Bidzilya OV, Budashkin YuI, Zhakov AV, Kostjuk IYu (2011). New and interesting records of Microlepidoptera from Ukraine. Eversmannia 25-26: 64-74. [In Russian]

Bigot L, Picard J (1996) Pterophoridae. In: Karsholt O, Razowski J (Eds) The Lepidoptera of Europe. A Distributional Checklist. Apollo Books, Stenstrup, 160-165.

Budashkin YuI (2004) The results of two decades of steady-state study of Lepidoptera fauna Karadag Nature Reserve. Karadag. History. Geology. Botanic. Zoology. SONAT, Simferopol': 323-366. [In Russian]

Budashkin YuI (2006) The materials on Lepidopterofauna of the Kazantip nature reserve. Trudy Nikitskogo botanicheskogo sada, Nacional'nogo nauchnogo centra 126: 263-291. [In Russian]

Budashkin YuI, Savchuk VV (2008) New faunal and bionomic Data of Crimean Lepidoptera. Optimization and Protection of Crimean Ecosystems. TNU, Simferopol', 18: 3-11. [In Russian]

Buszko J (1996) Gracillariidae. In: Karsholt O, Razowski J (Eds) The Lepidoptera of Europe. A Distributional Checklist. Apollo Books, Stenstrup, 48-54.

De Prins J, De Prins W (2016) Global Taxonomic Database of Gracillariidae (Lepidoptera). World Wide Web electronic publication. http://www.gracillariidae.net [accessed 27 May 2017] 
Deschka G (1982) Bucculatrix pannonica n. sp. (Lepidoptera, Bucculatricidae). Zeitschrift Arbeitsgemeinschaft Österreichischer Entomologen 34(1/2): 37-48.

Elsner G, Huemer P, Tokár Z (1999) Die Palpenmotten (Lepidoptera, Gelechiidae) Mitteleuropas. F. Slamka, Bratislava, 208 pp.

Falkovitsh MI, Bidzilya OV (2009) A list of gelechiid moths (Lepidoptera, Gelechiidae) of the Southern Kyzylkum. Proceedings of Zoological museum Kiev Taras Shevchenko national university 5: 65-98. [In Russian]

Hormuzaki K (1907) Die Schmetterlinge (Lepidoptera) der Bukowina. III Tiel. Familien Pyralidae bis Micropterigidae. Verhandlungen der Zoologish-Botanischen Gesselschaft in Wien 57: 34-104.

Huemer P, Karsholt O (1999) Gelechiidae I (Gelechiinae: Teleiodini, Gelechiini). In: Huemer P, Karsholt O, Lyneborg L (Eds) Microlepidoptera of Europe, 3. Apollo Books, Stenstrup, 356 pp.

Huemer P, Karsholt O (2010) Gelechiidae II (Gelechiinae: Gnorimoschemini). In: Huemer P, Karsholt O, Nuss M (Eds) Microlepidoptera of Europe, 6. Apollo Books, Stenstrup, 586 pp.

Huemer P, Lopez-Vaamonde C, Triberti P (2016) A new genus and species of leaf-mining moth from the French Alps, Mercantouria neli gen. n., sp. n. (Lepidoptera, Gracillariidae). Zookeys 586: 150-162. https://doi.org/10.3897/zookeys.586.8375

Gershenzon ZS (1988) Semejstvo vyemchatokrylyje moli - Gelechiidae. In: Dolin VG, Stovbchatyj VN (Eds) Vrediteli sel'skohosjajstvennyh kul'tur i lesnyh nasazhdenij. T. 2. Vrednyje chlenistonogije, pozvonochnyje. Urozhai, Kiev, 289-296. [In Russian]

Junnilainen J, Karsholt O, Nupponen K, Kaitila J-P, Nupponen T, Olschwang V (2010) The gelechiid fauna of the Southern Ural mountains, part II: list of recorded species with taxonomical notes (Lepidoptera, Gelechiidae). Zootaxa 2367: 1-68.

Kaila L (1992) The Elachistidae of southern Siberia and Central Asia, with description of five new species (Lepidoptera). Entomologica Fennica 3: 177-194.

Kaila L, Nupponen K, Junnilainen J, Nupponen T, Kaitla J-P, Olschwang V (2003) Contribution to the fauna of Elachistidae (Lepidoptera) of the Southern Ural Mountains. Entomologica Fennica 14: 65-90.

Karsholt O, Riedl T (1996) Gelechiidae. In: Karsholt O, Razowski J (Eds) The Lepidoptera of Europe. A Distributional Checklist. Apollo Books, Stenstrup: 103-122.

Kawahara AY, Plotkin D, Ohshima I, Lopez-Vaamonde C, Houlihan PR, Breinholt JW, Kawahara AY, Xiao L, Regier JC, Davis DR, Kumata T, Sohn JC, De Prins J, Mitter Ch (2017) A molecular phylogeny and revised higher-level classification for the leaf-mining moth family Gracillariidae and its implications for larval host use evolution. Systematic Entomology 42(1): 60-81. https://doi.org/10.1111/syen.12210

Kemal M, Koçak AO (2017) A gelechiid species, new for the fauna of Turkey (Lepidoptera). Miscellaneous Paper (Centre for Entomological Studies Ankara) 163: 1-3.

Kosakevich ZM (1978) Corn borer - Ostrinia scapulalis Walker (Lepidoptera, Pyraustidae) in the Ukraine. Vestnik Zoologii 2: 27-30. [In Russian]

Ljubomudrov IS (1917) Materialy k faune listovertok i molei Kievskoi gubernii. Materialy k poznaniju fauny jugo-zapadnoi Rossii, izdavaemye Kievskim ornitologitcheskim obshchestvom imeni K.E. Kesslera pod obshchei redaktsiei V.M. Artobolevskogo 2: 34-46. [In Russian]

Lvovsky A (1996) Oecophoridae. In Karsholt O and Razowski J (Eds) The Lepidoptera of Europe. A Distributional Checklist. Apollo Books, Stenstrup, 78-83.

Lvovsky AL (2006) Check-list of the broad-winged and flat moths (Lepidoptera: Oecophoridae, Chimabachidae, Amphisbatidae, Depressariidae) of the fauna of Russia and adjacent countries. Proceedings of the Zoological Institute, St. Petersburg 307, 119 pp. [In Russian]

Lvovsky AL (2008) Depressariidae. In: Sinev SYu (Ed.) Catalogue of the Lepidoptera of Russia. KMK Scientific Press Ltd., St. Petersburg, Moscow, 53-57. [In Russian]

Nowicki M (1860) Enumeratio Lepidopterorum Haliciae orientalis. Instituti Staropingiani, Leopoli, 269 pp. [+ xvi +1 pl.] https://doi.org/10.5962/bhl.title.66986 
Parenti U (1996) Elachistidae. In: Karsholt O, Razowski J (Eds) The Lepidoptera of Europe. A Distributional Checklist. Apollo Books, Stenstrup, 68-73.

Pastoralis G, Slamka F (2015) Occurrence of Phycita torrenti Agenjo, 1962 in Hungary (Lepidoptera: Pyralidae, Phycitinae). Microlepidoptera.hu 8: 23-28.

Petersen G, Gaedike R (1996) Tineidae. In: Karsholt O, Razowski J (Eds) The Lepidoptera of Europe. A Distributional Checklist. Apollo Books, Stenstrup: 31-38.

Piskunov VI, Uskov MV (2006) Two new species of gelechiid moths (Lepidoptera: Gelechiidae) from the center of European Russia. Eversmannia 5: 3-5. [In Russian]

Ponomarenko MG (2008) Gelechiidae. In: Sinev SYu (Ed.) Catalogue of the Lepidoptera of Russia. KMK Scientific Press Ltd., St. Petersburg, Moscow: 87-106. [In Russian]

Rákosy L, Goia M, Kovács Z (2003) Catalogul Lepidopterelor României. Societatea Lepidopterologicâ Romanâ, Cluj-Napoca, 447 pp.

Schille F (1930) Fauna motyli Polski. II. Prace Monograficzne Komisji Fiziograficznej. PAU, Krakow, 7, 358 pp.

Sinev SYu (1986) 57. Sem. Phycitidae. In: Medvedev GS (Ed.) Opredelitel' nasekomyh evropejskoj chasti SSSR. Tom 4. Cheshujekrylyje. Chast' tret'ja. Nauka, Leningrad, 251-340. [In Russian]

Sinev SYu (2008a) Elachistidae. In: Sinev SYu (Ed.) Catalogue of the Lepidoptera of Russia. KMK Scientific Press Ltd., St. Petersburg, Moscow, 156-170. [In Russian]

Sinev SYu (2008b) Pyralidae. In: Sinev SYu (Ed.) Catalogue of the Lepidoptera of Russia. KMK Scientific Press Ltd., St. Petersburg, Moscow, 58-61. [In Russian]

Sinev SYu (2016) A review of the little known genus Wockia (Lepidoptera, Urodidae) in Russia. Zoosystematica Rossica 25(1): 173-179.

Slamka F (2013) Pyraloidea of Europe (Lepidoptera). Vol. 3. Pyraustinae \& Spilomelinae. F. Slamka, Bratislava, $357 \mathrm{pp}$.

Sovinskiy VV (1938) Moli (Lepidoptera: Tineidae s. lat.) tsentralnoi tchastyny Kievskoi oblasti. Zbirnyk prats' Zoologichnogo Museju, 21-22 (Trudy Institutu Zoologii ta Biologii AN URSR) 19: 3-95. [In Ukrainian]

Speidel W (1996) Pyralidae. In: Karsholt O, Razowski J (Eds) The Lepidoptera of Europe. A Distributional Checklist. Apollo Books, Stenstrup, 166-183.

Tokar Z, Lvovsky A, Huemer P (2005) Die Oecophoridae s.l. (Lepidoptera) Mitteleuropas. F. Slamka, Bratislava, $120 \mathrm{Ss}$.

Ustjuzhanin PJa, Kovtunovich VN (2008) Pterophoridae. In: Sinev SYu (Ed.) Catalogue of the Lepidoptera of Russia. KMK Scientific Press Ltd., St. Petersburg, Moscow, 151-155. [In Russian]

Zagulajev AK (1960) Fauna SSSR. Nasekomyje cheshuekrylyje. Nastojaschije moli (Tineidae). Chast' tret'ja. Podsemejstvo Tineinae. Izdatel'stvo Akademii Nauk SSSR, Moscow, Leningrad, 268 pp. [In Russian]

Zagulajev AK (1986) 52. Sem. Pterophoridae. In: Medvedev GS (Ed.) Opredelitel' nasekomyh evropejskoj chasti SSSR. Tom 4. Cheshujekrylyje. Chast' tret'ja. Nauka, Leningrad, 26-215. [In Russian] 